Marquette University

e-Publications@Marquette

Biological Sciences Faculty Research and

Publications

Biological Sciences, Department of

$5-2011$

\title{
To Duckweeds (Landoltia punctata), Nanoparticulate Copper Oxide is More Inhibitory than the Soluble Copper in the Bulk Solution
}

Jiyan Shi

Zhejiang University

Aamir D. Abid

University of California - Davis

Ian M. Kennedy

University of California - Davis

Krassimira R. Hristova

Marquette University, krassimira.hristova@marquette.edu

Wendy K. Silk

University of California - Davis

Follow this and additional works at: https://epublications.marquette.edu/bio_fac

Part of the Biology Commons

\section{Recommended Citation}

Shi, Jiyan; Abid, Aamir D.; Kennedy, Ian M.; Hristova, Krassimira R.; and Silk, Wendy K., "To Duckweeds (Landoltia punctata), Nanoparticulate Copper Oxide is More Inhibitory than the Soluble Copper in the Bulk Solution" (2011). Biological Sciences Faculty Research and Publications. 382.

https://epublications.marquette.edu/bio_fac/382 


\title{
To duckweeds (Landoltia punctata), nanoparticulate copper oxide is more inhibitory than the soluble copper in the bulk solution
}

\author{
Jiyan Shi \\ Department of Land, Air, and Water Resources, University of \\ California \\ Davis, $C A$
}

Department of Environmental Engineering, Zhejiang University

HangZhou, People's Republic of China

Aamir D. Abid

Department of Mechanical and Aeronautical Engineering,

University of California

Davis, $C A$

Ian M. Kennedy

Department of Mechanical and Aeronautical Engineering,

University of California

Davis, $C A$ 


\author{
Krassimira R. Hristova \\ Department of Land, Air, and Water Resources, University of \\ California \\ Davis, $C A$ \\ Department of Biological Sciences, Marquette University \\ Milwaukee, WI \\ Wendy K. Silk \\ Department of Land, Air, and Water Resources, University of \\ California \\ Davis, $C A$
}

\begin{abstract}
:
CuO nanoparticles (CuO-NP) were synthesized in a hydrogen diffusion flame. Particle size and morphology were characterized using scanning mobility particle sizing, Brunauer-Emmett-Teller analysis, dynamic light scattering, and transmission electron microscopy. The solubility of CuO-NP varied with both $\mathrm{pH}$ and presence of other ions. CuO-NP and comparable doses of soluble $\mathrm{Cu}$ were applied to duckweeds, Landoltia punctata. Growth was inhibited $50 \%$ by either $0.6 \mathrm{mg} \mathrm{L}^{-1}$ soluble copper or by $1.0 \mathrm{mg} \mathrm{L}^{-1} \mathrm{CuO}-$ NP that released only $0.16 \mathrm{mg} \mathrm{L}^{-1}$ soluble $\mathrm{Cu}$ into growth medium. A significant decrease of chlorophyll was observed in plants stressed by $1.0 \mathrm{mg}$ $\mathrm{L}^{-1} \mathrm{CuO}-\mathrm{NP}$, but not in the comparable $0.2 \mathrm{mg} \mathrm{L}^{-1}$ soluble $\mathrm{Cu}$ treatment. The $\mathrm{Cu}$ content of fronds exposed to $\mathrm{CuO}-\mathrm{NP}$ is four times higher than in fronds exposed to an equivalent dose of soluble copper, and this is enough to explain the inhibitory effects on growth and chlorophyll content.
\end{abstract}

Keywords: Copper, Copper oxide nanoparticles, Duckweed, Toxicity, Aquatic plants.

\title{
1. Introduction
}

Metal oxide nanoparticles are receiving increasing attention in a large variety of applications; efforts are underway in many laboratories to understand the potential for eco-toxicity (Boczkowski and Hoet, 2009; Nowack and Bucheli, 2007; Unrine et al., 2008). In particular copper oxide nanoparticles (CuO-NP) are being used in antifouling paints for boats (Saison et al., 2010), used in some inks, plastics, and antimicrobial coatings (Cioffi et al., 2005) and marketed for many

Environmental Pollution, Vol. 159, No. 5 (May 2011): pg. 1277-1282. DOI. This article is (C) Elsevier and permission has been granted for this version to appear in e-Publications@Marquette. Elsevier does not grant permission for this article to be further copied/distributed or hosted elsewhere without the express permission from Elsevier. 
applications including ceramics, electronics, and propellants (reviewed in Pan et al., 2010). Recently, air-borne CuO-NP have been shown to be more toxic to human lung epithelial cells than $\mu \mathrm{m}$ size particles (Karlsson et al., 2008, 2009; Midander et al., 2009).

In aqueous media metal oxide nanoparticles can form a suspension with particles that aggregate in clusters of particular sizes (Franklin et al., 2007). A certain amount of metal also dissolves, and the equilibrium solution depends on the composition of the medium. The toxic effects of metal oxide nanoparticles can be due to the effects of the dissolved ionic metal, or there may be special hazards from nanoparticles themselves due to enhanced bioactivity. Several authors have pointed out the importance of distinguishing the toxicity of nanoparticulate structure from heavy metal toxicity (Franklin et al., 2007; Griffitt et al., 2007; Karlsson et al., 2008, 2009). In this study we have manufactured $\mathrm{CuO}-\mathrm{NP}$ and characterized them with respect to particle size, aggregation, and the release of soluble $\mathrm{Cu}$ as a function of time, $\mathrm{pH}$, and presence of mineral nutrients. The toxicity of CuO-NP and the uptake of $\mathrm{Cu}$ into plant tissue were compared to a reference toxicant, $\mathrm{CuCl}_{2}$.

The bioassays for toxicity examined the inhibition of growth and the decrease in chlorophyll content of Landoltia punctata, a member of the duckweed family. Duckweeds, distributed worldwide in ponds, sloughs and irrigation ditches, are favorite subjects for bioassays because they are easily cultured on defined nutrient media. They have high capacity for heavy metal uptake and have been proposed for bioremediation of copper (Boniardi et al., 1999; Kanoun-Boule et al., 2009; Zayed et al., 1998). Duckweeds grow with a bifurcating pattern of frond production, so that when nutrients are abundant the number of fronds increases exponentially with time (Fig. 1; Lehman et al., 1981). The rate of population growth can be characterized by $\boldsymbol{D}$, the frond doubling time in the growth equation:

$$
N(t)=N_{0} 2^{t / D} \Rightarrow \log _{2} N(t)=\log _{2} N_{0}+t / D
$$

where $N(t)$ is the number $N$ of fronds at time $(t)$ produced by an initial number $N_{0}$. Thus the characteristic doubling time can be obtained as the reciprocal of the slope of the regression of $\log _{2}$ of the frond number vs time. Here, growth inhibition by ionic $\mathrm{Cu}$ and $\mathrm{CuO}-\mathrm{NP}$ is quantified as an increase in $D$.

Environmental Pollution, Vol. 159, No. 5 (May 2011): pg. 1277-1282. DOI. This article is $($ Elsevier and permission has been granted for this version to appear in e-Publications@Marquette. Elsevier does not grant permission for this article to be further copied/distributed or hosted elsewhere without the express permission from Elsevier. 

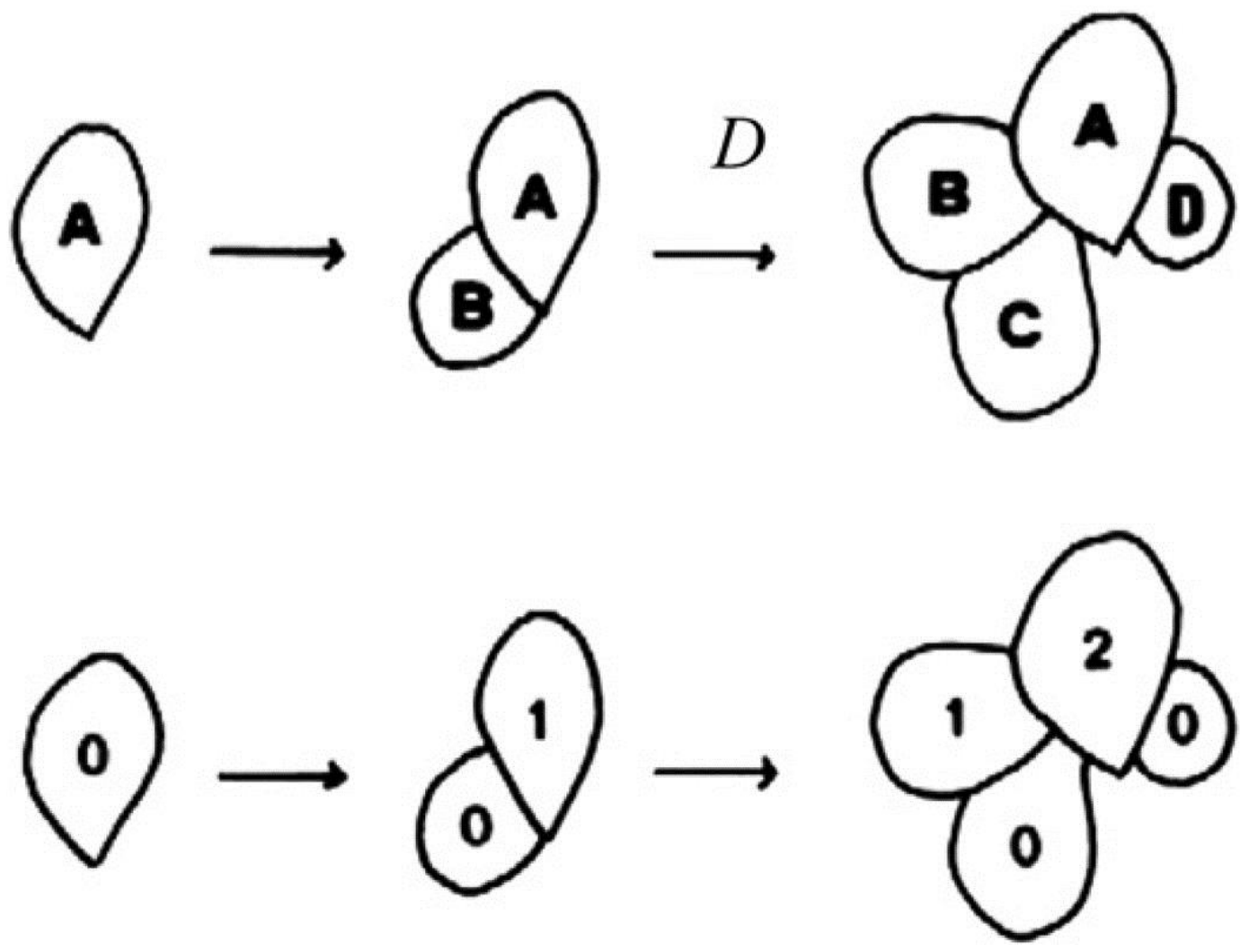

Fig. 1 Bifurcating frond production in duckweeds. Upper figures are lettered to show the order of appearance of fronds. Lower figures are numbered to show frond age (in terms of number of generations produced). In $D$ time units the number of fronds doubles.

\section{Materials and methods}

\subsection{Synthesis and characterization of CuO-NP}

Synthesis and characterization methods followed Rice et al. (2009). In brief, copper oxide nanoparticles were synthesized in the gas phase by introducing the vapor of the metal precursor into a hydrogen/air diffusion flame. The flame was stabilized on a $3 / 8^{\prime \prime}$ stainless steel tube and located in a vertical wind tunnel. The fuel stream consisted of a $1: 1$ mixture of $\mathrm{H}_{2}$ and $\mathrm{N}_{2}$ at a flow rate of 1.5 $\mathrm{I} / \mathrm{min}$. The entire fuel stream was passed through a cartridge containing copper acetylacetonate maintained at $160^{\circ} \mathrm{C}$ and located just below the exit of the tube. Copper acetylacetonate vapor pyrolyzes in the temperature range from 300 to $700{ }^{\circ} \mathrm{C}$ to produce metallic copper. The organic products were exposed to a highly oxidizing environment in the flame at which temperature organic compounds were converted completely to carbon dioxide and water 
(Vonhoene et al., 1958). Particles in the flame effluent were extracted using a vacuum probe and collected on PTFE membrane filters (Advantec Inc.) with a pore size of $0.2 \mu \mathrm{m}$. The aerosol size distribution at the sampling location was measured using a scanning mobility particle sizer (SMPS, TSI Inc.) Particle size and morphology were observed using a Phillips CM-12 transmission electron microscope. The particle crystalline phase was identified using a Scintag powder $\mathrm{x}$-ray diffractometer with $\mathrm{Cu} \mathrm{Ka}$ radiation operated at $45 \mathrm{kV}$ and $40 \mathrm{~mA}$. Nanoparticle surface area measurements were done by the Brunauer-Emmett-Teller (BET) method using an Autosorb-1 instrument (Quantachrome Instruments, Boynton Beach, FL). For the BET analysis, about $60 \mathrm{mg}$ of powder sample was measured, and nitrogen was used as the adsorbate. Time evolution of nanoparticles aggregation analysis was studied using a dynamic light scattering (DLS) instrument (Brookhaven ZetaPlus, Worcestershire, UK). The particle concentration at the start of the DLS experiment was $1 \mathrm{mg} \mathrm{L}^{-1}$ in Hoagland's solution, and the solution was probe sonicated for one minute to disperse the particles. For the rest of the DLS the solution is left unperturbed.

Nanoparticles' dissolution was assessed first using the equilibrium dialysis method of Franklin et al. (2007). Spectra/Por 7 dialysis membrane (ordered from Spectrumlabs.com) of $1000 \mathrm{Da}$ molecular weight cutoff (nominal pore size) and $45 \mathrm{~mm}$ diameter was cut into $10 \mathrm{~cm}$ lengths and rinsed thoroughly in Milli-Q ultra-highpurity water prior to use. The dialysis cells were formed by filling the membrane tubes with Milli-Q water and sealing them with plastic dialysis clips which had been cleaned by soaking in $1 \%(\mathrm{v} / \mathrm{v})$ nitric acid for several hours and thoroughly rinsing in Milli-Q water. The volume of the cells was approximately $10 \mathrm{~mL}$. Test solutions were prepared by adding CuO-NP powder $(10 \mathrm{mg} / \mathrm{L})$ and bulk $\mathrm{CuO}$ powder $(10 \mathrm{mg} / \mathrm{L})$ to water or Hoaglands solution buffer buffered with MES. Dialysis cells were added to the test solution stirred in a beaker. To minimize dilution effects, care was taken to keep the volume of the dialysis cells below $5 \%$ of the total solution volume. At each sampling time, two cells were removed and sampled by pipette into polycarbonate vials, then used for particle dissolution determination. Samples of the external test solution were also taken at each time point for a measurement of $\mathrm{pH}$. A faster and less expensive method was to determine dissolved copper present in the supernatant of samples centrifuged at $100,000 \mathrm{~g}$ for $30 \mathrm{~min}$. For both dialysis and ultracentrifugation separation methods, copper assay was by atomic absorption spectroscopy using a Perkin Elmer AAnalyst 800 or (for dilute samples) by ICP-MS at the Interdisciplinary Center for Plasma Mass Spectrometry at UC Davis. The ICP-MS system is an Agilent

Environmental Pollution, Vol. 159, No. 5 (May 2011): pg. 1277-1282. DOI. This article is (C) Elsevier and permission has been granted for this version to appear in e-Publications@Marquette. Elsevier does not grant permission for this article to be further copied/distributed or hosted elsewhere without the express permission from Elsevier. 
NOT THE PUBLISHED VERSION; this is the author's final, peer-reviewed manuscript. The published version may be accessed by following the link in the citation at the bottom of the page.

7500a quadrupole instrument coupled to a Nd:YAG New Wave UP 213 laser.

\subsection{Duckweed culturing and growth analysis}

Duckweed, L. (Spirodela) punctata (G. Mey.) Les \& D. J. Crawford, was obtained from Dean Kelch (California Department of Food and Agriculture, Plant Pest Diagnostics Laboratory, CDA Herbarium, 3294 Meadowview Road, Sacramento, CA 95832-1448) and maintained in dilute Hoagland's solution. To kill contaminating algae before experimental treatments, plants were surface sterilized for five minutes in $0.5 \% \mathrm{NaClO}$ then placed in half-strength Hoagland's solution for $48 \mathrm{~h}$. Because preliminary results showed that plant growth and CuO-NP dissolution were both $\mathrm{pH}$ dependent, growth incubation was at constant $\mathrm{pH}$ 6.0; and nutrient media buffered with MES were prepared before addition of CuO-NP. For the growth assays, five $\mathrm{ml}$ of incubation medium were pipetted into sterile petri dishes, five to ten replicates per treatment. A pilot study compared the number of fronds present $96 \mathrm{~h}$ after treatment with a range of concentrations of $\mathrm{CuCl}_{2}, \mathrm{CuO}-\mathrm{NP}$ and bulk CuO. Then growth curves were obtained with treatments of $0.2 \mathrm{mg} \mathrm{L}^{-1}(3.15 \mu \mathrm{M}$, "low Cu salt") or $0.6 \mathrm{mg} \mathrm{L}^{-1} \mathrm{Cu}\left(9.45 \mu \mathrm{M}\right.$, "high Cu salt") supplied as $\mathrm{CuCl}_{2}$, or 1.0 $\mathrm{mg} \mathrm{L}^{-1}$ CuO-NP ("CuO-NP"). Ten fronds were added to each dish on day one. The culture dishes were maintained on a shaker set at a gentle speed in a Conviron growth chamber maintained at $14 \mathrm{~h}$ days at $24{ }^{\circ} \mathrm{C}$ and $10 \mathrm{~h}$ nights at $20^{\circ} \mathrm{C}$ (Fig. 2). Nutrient medium was replaced on alternate days. Light was provided by a mix of incandescent and fluorescent bulbs (Phillips warm white) providing $180 \mu \mathrm{mol} \mathrm{m} \mathrm{m}^{-2} \mathrm{~s}^{-1}$ at bench height. Fronds were counted and $\mathrm{pH}$ was monitored (and adjusted if necessary to $\mathrm{pH}$ 6.0) daily. A magnifying glass was used to count fronds; only fronds that had emerged from their growth pockets were counted. Five or six replicate growth assays were conducted for each treatment. The $95 \%$ significance level of the doubling coefficient was computed using the $t$ statistic to obtain the confidence level of the slope of the growth equation and then taking the reciprocal of the slope with and without the confidence interval.

Environmental Pollution, Vol. 159, No. 5 (May 2011): pg. 1277-1282. DOI. This article is (C) Elsevier and permission has been granted for this version to appear in e-Publications@Marquette. Elsevier does not grant permission for this article to be further copied/distributed or hosted elsewhere without the express permission from Elsevier. 
NOT THE PUBLISHED VERSION; this is the author's final, peer-reviewed manuscript. The published version may be accessed by following the link in the citation at the bottom of the page.
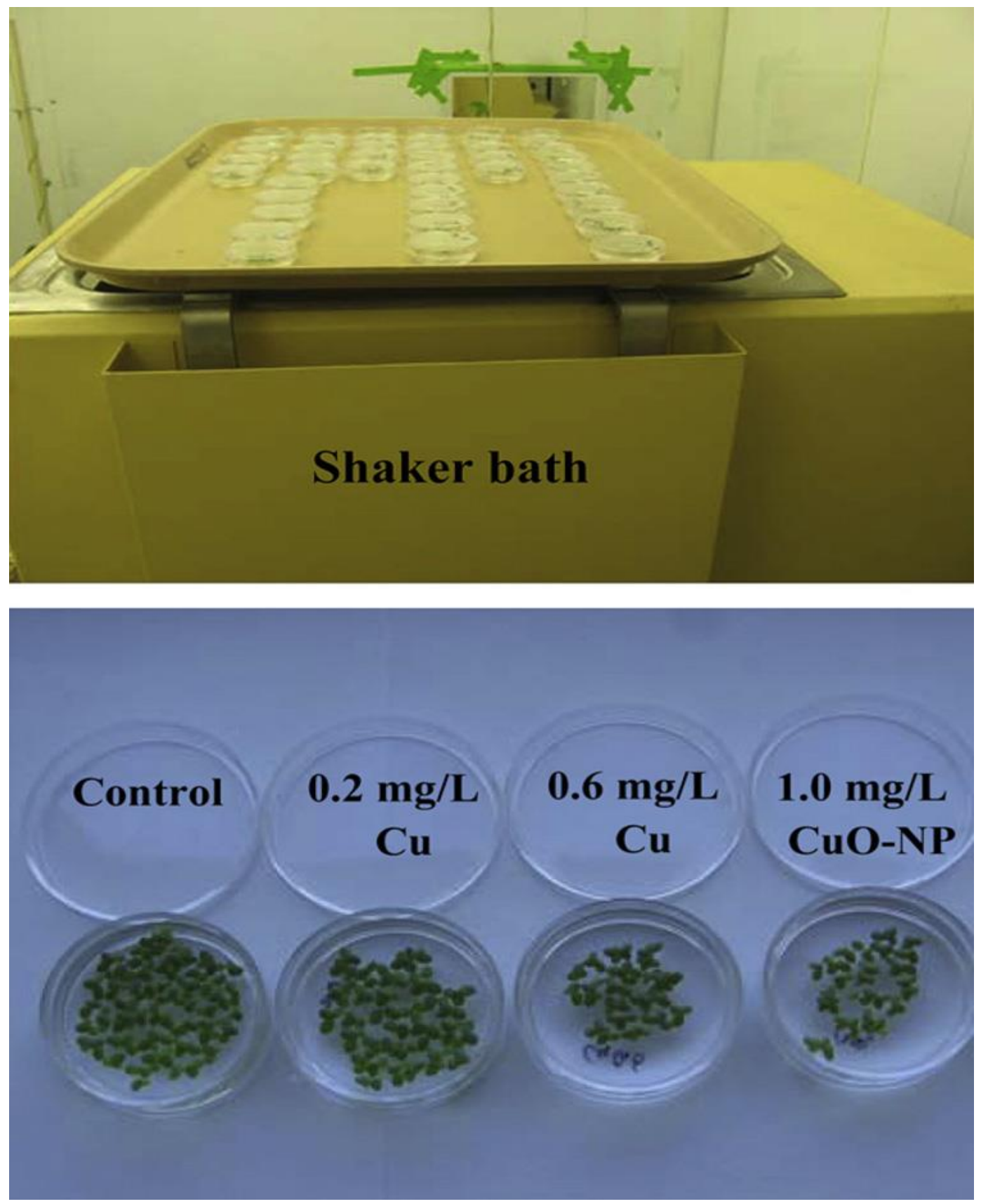

Fig. 2 Experimental setup for growth inhibition studies.

\subsection{Assays for chlorophyll and copper uptake}

Photosynthetic pigments were assayed by standard spectrophotometric assays. Fronds (approximately $100 \mathrm{mg}$ fresh weight) were extracted in $10 \mathrm{ml}$ cold ethanol and acetone (1:1 in 
volume). The absorbance of pigment extract was measured at wavelengths of 663,645 , and $470 \mathrm{~nm}$ with a spectrophotometer. The contents of Chlorophyll ( $\mathrm{Chl})$ a and $\mathrm{Chl} b$ were calculated from: $\mathrm{Chl} \mathrm{a}=$ $12.72 A_{663}-2.69 A_{645} \mathrm{Chl} b=22.9 A_{645}=4.68 A_{663}$. Five replicate assays were performed per treatment.

Elemental $\mathrm{Cu}$ in leaf and frond tissue was determined by atomic absorption spectroscopy using a Perkin Elmer AAnalyst 800. Plants were desorbed $15 \mathrm{~min}$ in cold $10 \mathrm{mM} \mathrm{CaCl}_{2}$. Roots or fronds were excised, dried at $75^{\circ} \mathrm{C}$ for two days and weighed. Samples (approximately $250 \mathrm{mg}$ frond tissue or $100 \mathrm{mg}$ root tissue) were digested in $1 \mathrm{M} \mathrm{HCl}$ for $48 \mathrm{~h}$ and diluted with deionized water. The solution was transferred to polystyrene tubes and refrigerated until analysis by AA. Standard curves were made with $\mathrm{CuSO}_{4}$ and $\mathrm{ZnSO}_{4}$, and three replicate samples were analyzed per treatment.

\section{Results}

\subsection{Characterization of CuO-NP}

The primary particles that are formed in the flame form aggregates; and the aerosol size distribution, as measured by the scanning mobility particle sizer shown in Fig. 3A, was log-normal with a count mean mobility diameter of $43 \mathrm{~nm}$. The copper oxide primary particle size, estimated by transmission electron microscopy, is between 10 and $15 \mathrm{~nm}$, although larger aggregates form as artifacts due to drying of solution on TEM grids (Fig. 3B). X-ray diffraction analysis revealed the presence of only one crystal phase, corresponding to monoclinic CuO (Fig. 4).

Environmental Pollution, Vol. 159, No. 5 (May 2011): pg. 1277-1282. DOI. This article is @ Elsevier and permission has been granted for this version to appear in e-Publications@Marquette. Elsevier does not grant permission for this article to be further copied/distributed or hosted elsewhere without the express permission from Elsevier. 
NOT THE PUBLISHED VERSION; this is the author's final, peer-reviewed manuscript. The published version may be accessed by following the link in the citation at the bottom of the page.

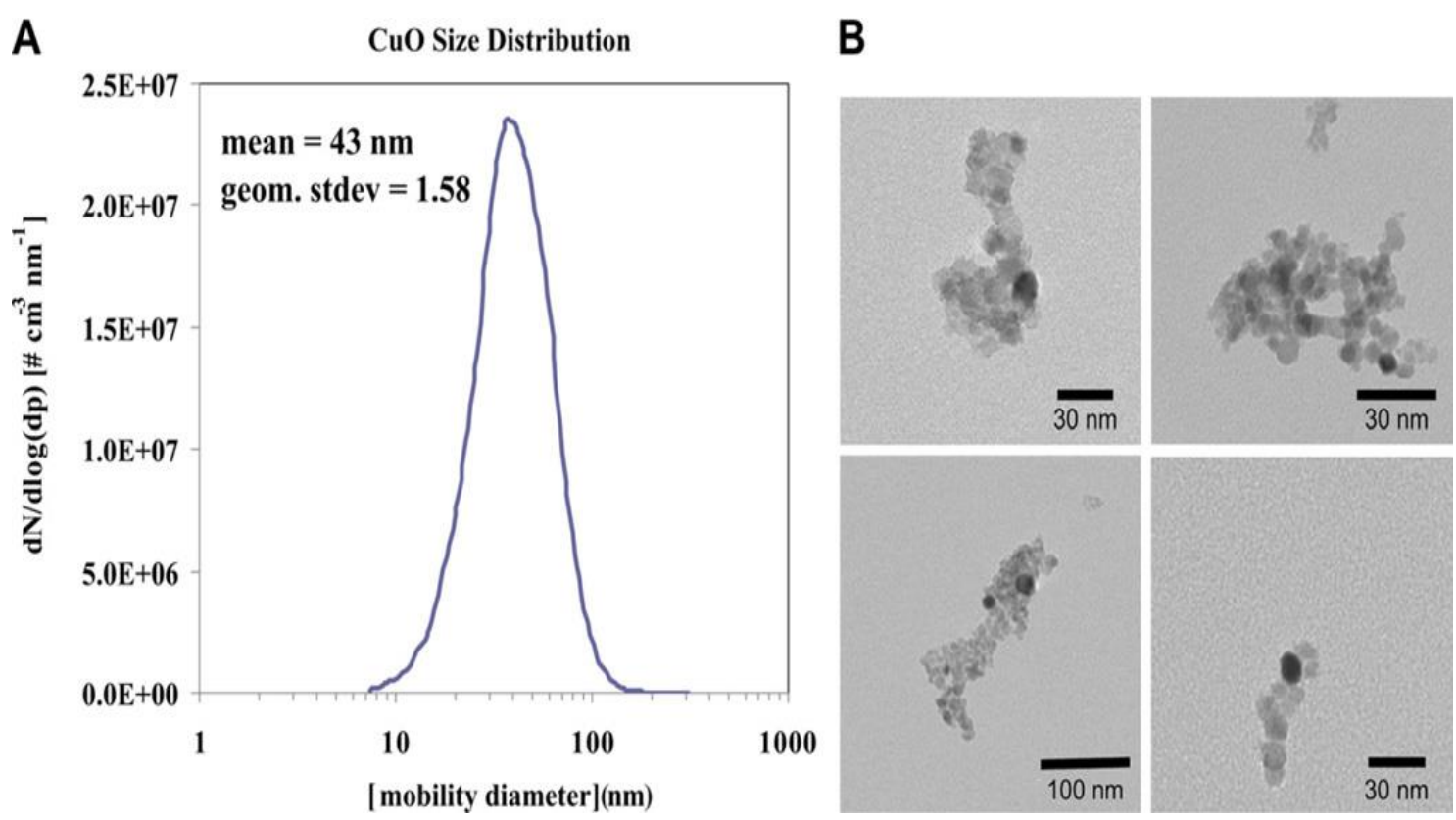

Fig. 3 (A) Particle size distribution by scanning mobility particle sizer as sampled from the flame. (B) CuO nanoparticles characterized by TEM. These are representative images of particles after drying the suspension on the microscope grid, which induced aggregation.

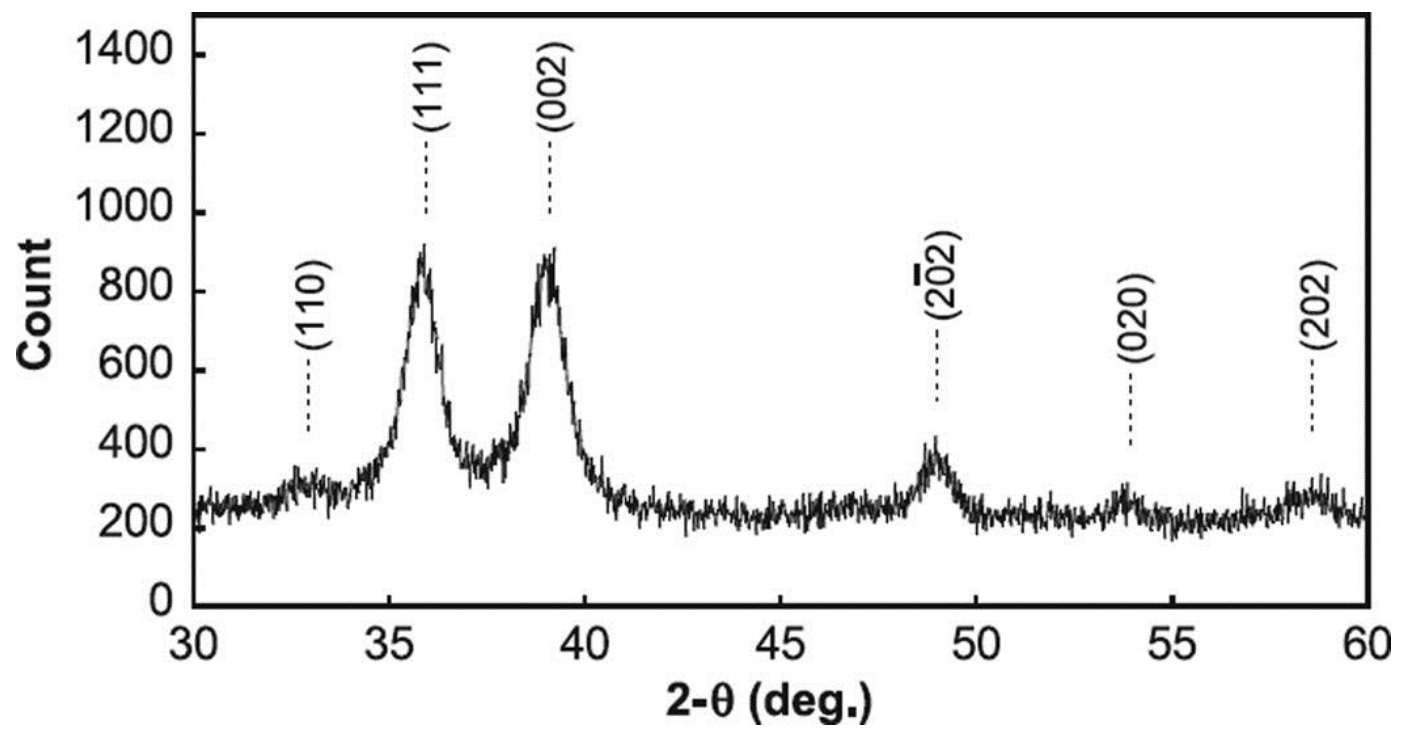

Fig. 4

XRD result of flame synthesized copper oxide nanoparticles. The vertical lines are the major lines from monoclinic CuO XRD spectra.

To investigate the stability of the copper oxide particles in Hoagland's solution over time, particle size measurements were 
determined by DLS as shown in Fig. 5. The number weighted particle diameter for the first seven days of the experiment is constant at $9 \mathrm{~nm}$ and thereafter the particles grow slightly by aggregation.

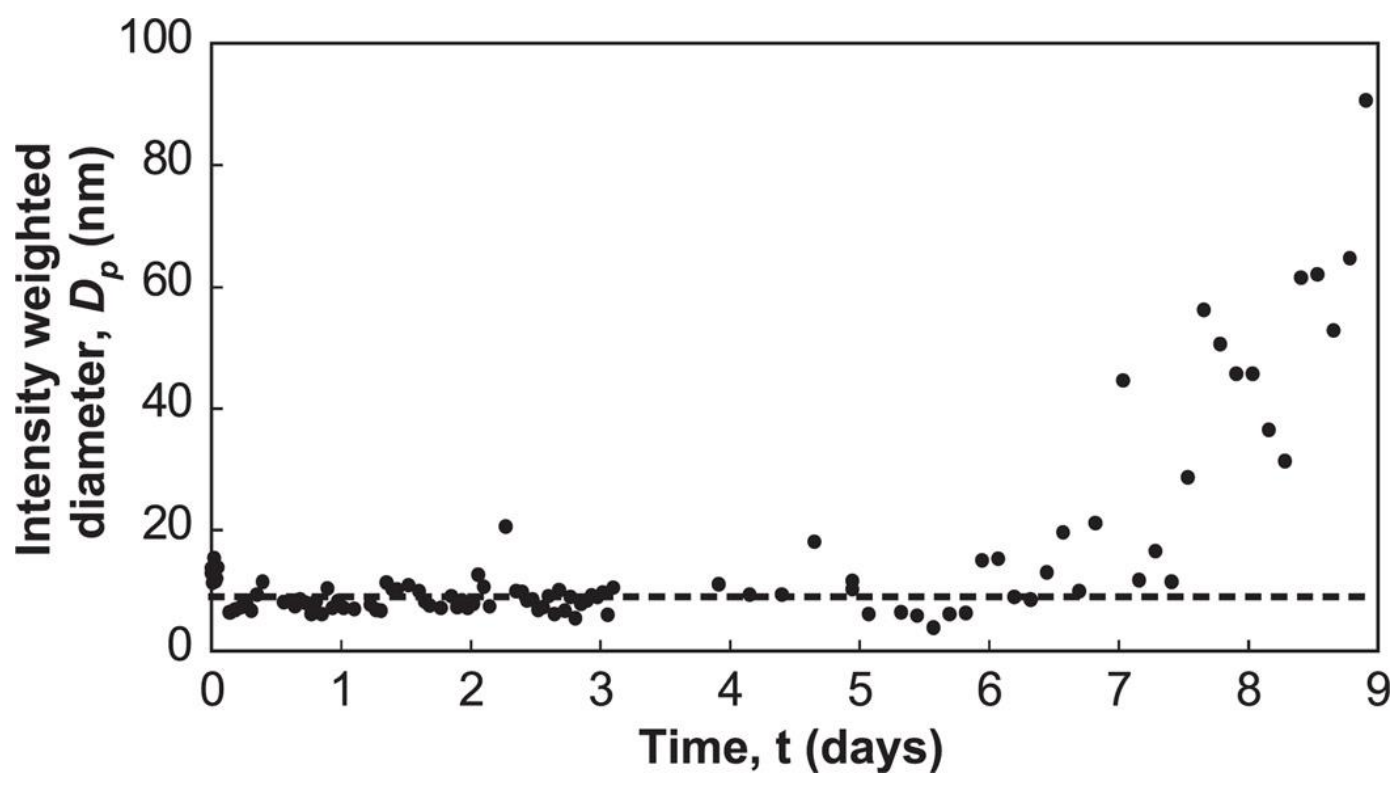

Fig. 5 Time course study of particle size by dynamic light scattering. Symbols are measured data; dashed line is the mean particle size for first seven days ( $=9 \mathrm{~nm}$ ).

The BET measurement indicated that the copper oxide nanoparticles have a specific surface area of $141 \pm 1 \mathrm{~m}^{2} \mathrm{~g}^{-1}$. The BET effective diameter is determined by,

$$
d_{\mathrm{BET}}=\frac{6}{A_{\mathrm{s}} \rho}
$$

where $A_{\mathrm{s}}$ is the specific surface area and $\rho$ is the particle density of $6.4 \mathrm{~g} \mathrm{~cm}^{-3}$ and $d_{\mathrm{BET}}$ is $6.7 \mathrm{~nm}$. The primary particle size measured by DLS, TEM and BET is comparable.

\subsection{Release of soluble copper from CuO-NP suspensions}

Preliminary experiments established that for the CuO-NP suspensions, the measured soluble $\mathrm{Cu}$ concentration in the supernatant from ultracentrifugation is indistinguishable from that of the dialysate obtained from nanopore dialysis (Fig. 6). Assays for 
soluble $\mathrm{Cu}$ released by CuO-NP were therefore based on the quicker and less expensive ultracentrifugation technology.

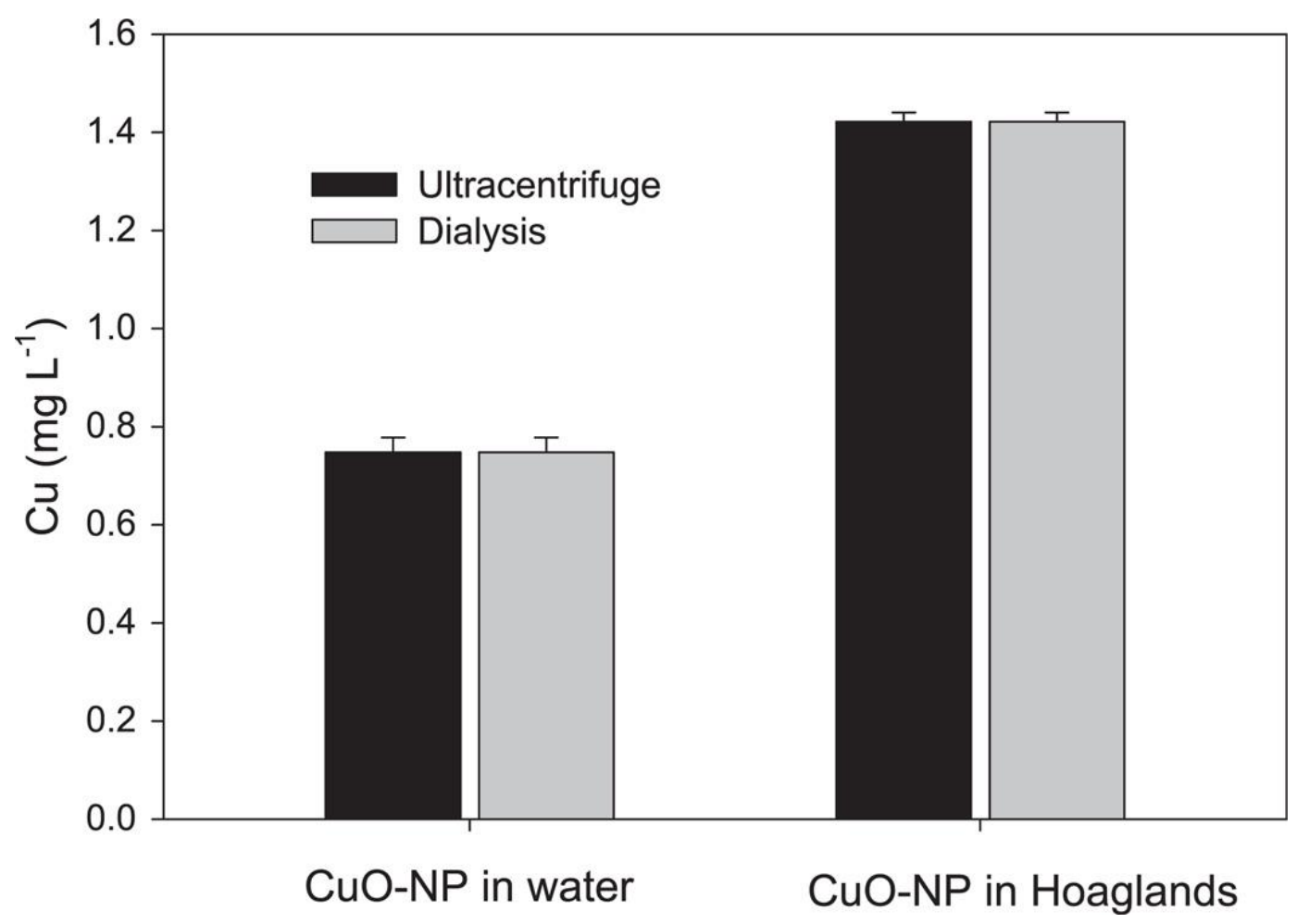

Fig. 6 Assay of Cu released by $10 \mathrm{mg} \mathrm{L}^{-1}$ CuO-NP suspension. Each copper determination is the average of two replicate assays; vertical lines show the standard deviation (SD).

Dissolution of CuO-NP increases with time over a two day period; more than $80 \%$ of the soluble $\mathrm{Cu}$ that will be released appears within $48 \mathrm{~h}$ after addition of water (Fig. 7). The CuO-NP release 14 times more $\mathrm{Cu}$ than bulk $\mathrm{CuO}$. Dissolution is $\mathrm{pH}$ dependent, as expected (Fig. 8). The presence of the nutrient solution also increases $\mathrm{Cu}^{2+}$ dissolution. In half-strength Hoaglands solution $10 \mathrm{mg} \mathrm{L}^{-1} \mathrm{CuO}-$ NP releases $6.4 \mathrm{mg} \mathrm{L}^{-1}$ soluble copper at $\mathrm{pH} 3.2$ but only $1.1 \mathrm{mg} \mathrm{L}^{-1}$ soluble copper at pH 7.0 (Fig. 8) after 48 h. In pure water the nanoparticulate suspension releases 3.6 and $0.7 \mathrm{mg} \mathrm{L}^{-1}$ soluble copper at, respectively, $\mathrm{pH} 3.2$ and 7.0. 
NOT THE PUBLISHED VERSION; this is the author's final, peer-reviewed manuscript. The published version may be accessed by following the link in the citation at the bottom of the page.

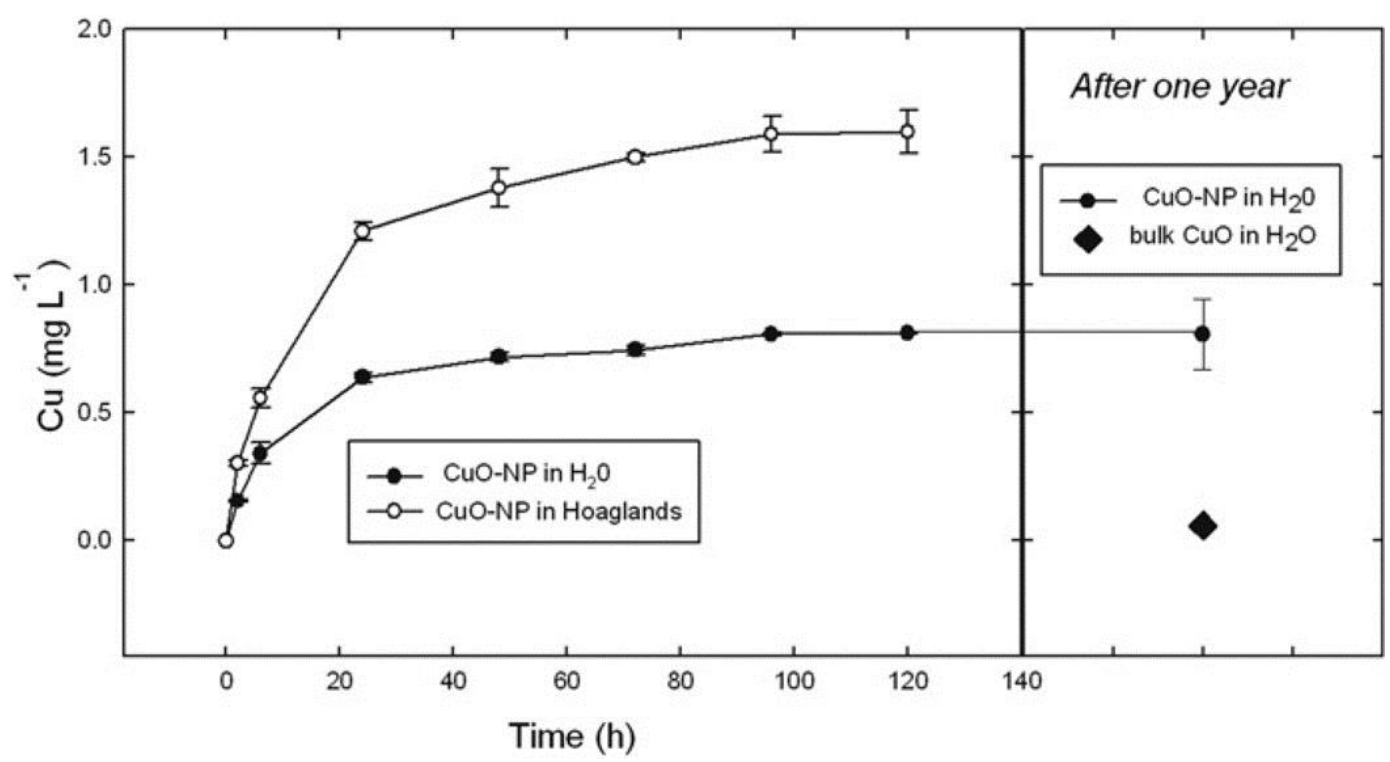

Fig. 7 Time dependence of $\mathrm{Cu}$ dissolution from $10 \mathrm{mg} \mathrm{L}^{-1} \mathrm{CuO}-\mathrm{NP}$ or bulk CuO suspension. Each copper determination is the average of two replicate assays (in the first week, left) or five replicate assays (after one year, right); vertical lines show one SD.

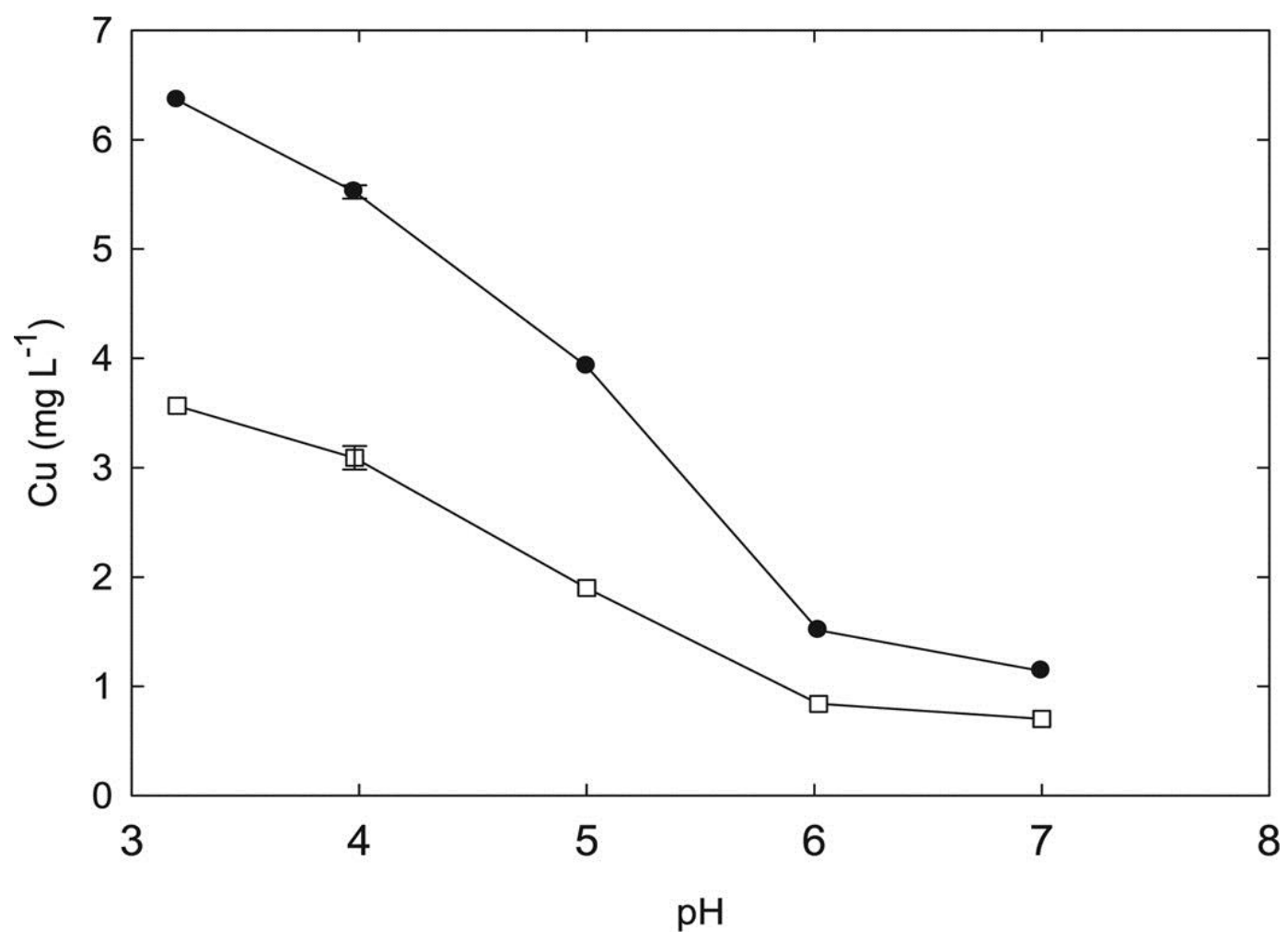

Fig. $8 \mathrm{pH}$ dependence of $\mathrm{Cu}$ dissolution from $10 \mathrm{mg} \mathrm{L}^{-1} \mathrm{CuO}-\mathrm{NP}$ suspension. Statistics as for Fig. 6. 
NOT THE PUBLISHED VERSION; this is the author's final, peer-reviewed manuscript. The published version may be accessed by following the link in the citation at the bottom of the page.

\subsection{Growth inhibition}

To establish the toxicity for the different copper compounds, a pilot study compared the number of fronds produced during $96 \mathrm{~h}$ of incubation with a range of concentrations of $\mathrm{CuCl}_{2}$ ("Cu salt"), $\mathrm{CuO}-\mathrm{NP}$ and bulk $\mathrm{CuO}$. The sensitivity of $L$. punctata to $\mathrm{Cu}$ salt was within the range reported for other species in the Lemnaceae (Zayed et al.,1998; Boniardi et al.,1999; Prasad et al., 2001; Kanoun-Boule et al., 2009). The bulk $\mathrm{CuO}$ had little bioactivity; the slight growth inhibition can be explained by the $\mathrm{Cu}$ released to the solution. However, CuO-NP inhibited growth substantially (Fig. 9). The concentration that reduces growth to half of control values is $0.5 \mathrm{mg} \mathrm{L}^{-1}$ for $\mathrm{Cu}$ salt, $0.8 \mathrm{mg} \mathrm{\textrm {L } ^ { - 1 }}$ for $\mathrm{CuO}-\mathrm{NP}$, and is not achieved with bulk $\mathrm{CuO}$ in the range tested. Above a certain toxic threshold fronds died more rapidly than they were produced. This threshold is $1.0 \mathrm{mg} \mathrm{L}^{-1}$ for $\mathrm{Cu}$ salt and $2.0 \mathrm{mg} \mathrm{L}^{-1}$ for CuO-NP.

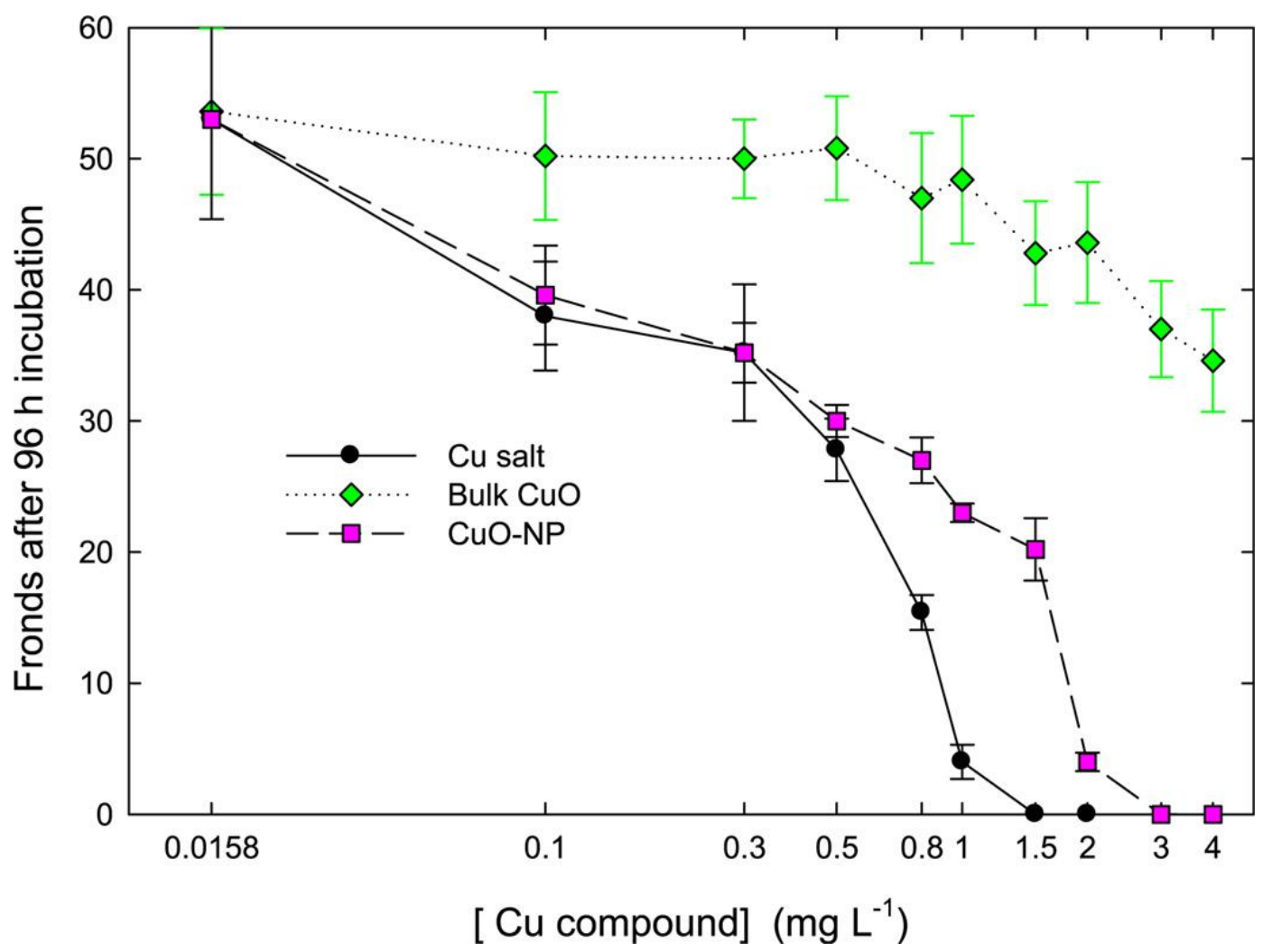

Fig. 9 Short term experiment to determine dependence of Lemna growth on $\mathrm{Cu}$ compound concentration. Symbols show average values for five replicates; vertical lines are one SD.

Environmental Pollution, Vol. 159, No. 5 (May 2011): pg. 1277-1282. DOI. This article is (C) Elsevier and permission has been granted for this version to appear in e-Publications@Marquette. Elsevier does not grant permission for this article to be further copied/distributed or hosted elsewhere without the express permission from Elsevier. 
NOT THE PUBLISHED VERSION; this is the author's final, peer-reviewed manuscript. The published version may be accessed by following the link in the citation at the bottom of the page.

To quantify effects on growth the following five treatments were chosen based on the concentration dependence: "control" treatments were nutrient (half-strength Hoaglands) solutions containing 0.0158 $\mathrm{mg} \mathrm{L}^{-1} \mathrm{Cu}$, "lowCusalt" treatments had $0.2 \mathrm{mg} \mathrm{L}^{-1} \mathrm{Cu}^{2+}$, "high $\mathrm{Cu}$ salt" had $0.6 \mathrm{mg} \mathrm{L}^{-1} \mathrm{Cu}^{2+}$, and "CuO-NP" had $1.0 \mathrm{mg} \mathrm{L}^{-1} \mathrm{CuO}-\mathrm{NP}$ suspension releasing $0.16 \mathrm{mg} \mathrm{L}^{-1}$ soluble $\mathrm{Cu}$ to the medium. If CuO-NP affects growth simply by releasing soluble $\mathrm{Cu}^{2+}$, then the low $\mathrm{Cu}$ salt and the CuO-NP treatments should produce similar inhibitions.

Growth curves were obtained by counting fronds daily for nine days in nutrient medium maintained at $\mathrm{pH} 6.0$ with one of four treatments described above. Frond production was slightly inhibited by the low copper treatment and inhibited more than $50 \%$ by both the high copper treatment and the nanoparticulate suspensions (Fig. 10A). Effect on frond production was quantified by using dimensionless curves (Fig. 10B) suggested by Eq. (1) to calculate the doubling times for each treatment, shown in Table 1. The growth analyses were consistent in showing that the CuO-NP suspension that released 0.16 $\mathrm{mg} \mathrm{L}^{-1}$ to the growth medium actually inhibited frond production to approximately the same extent as $0.60 \mathrm{mg} \mathrm{L}^{-1}$ elemental copper. 
NOT THE PUBLISHED VERSION; this is the author's final, peer-reviewed manuscript. The published version may be accessed by following the link in the citation at the bottom of the page.

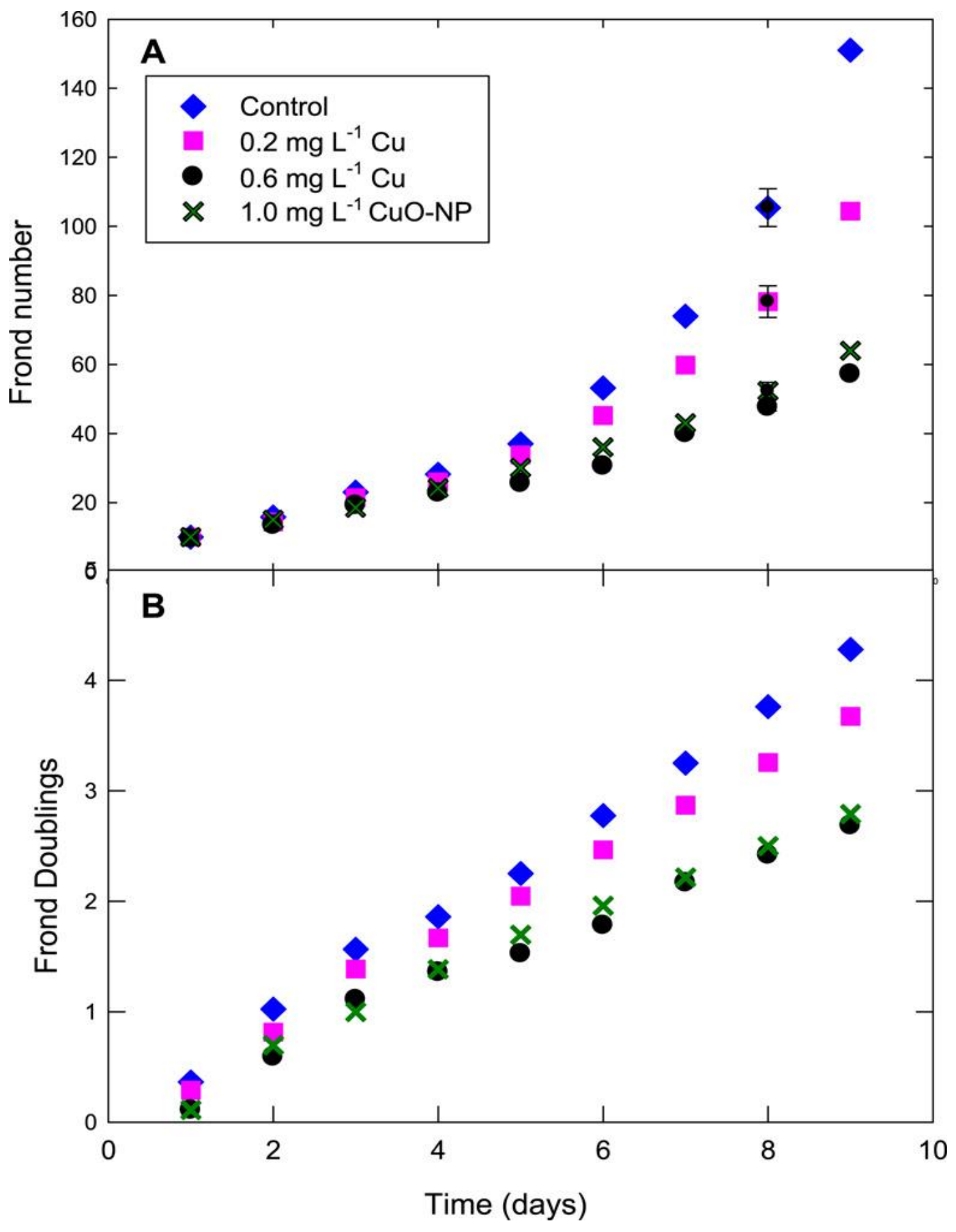

Fig. 10 Growth curves (Above) Frond production (Below) Dimensionless growth curve suggested by Fig. 1. Symbols show average values for six replicates; vertical lines are one SD. 


\begin{tabular}{lrrrr}
\hline Treatment & Control & Low Cu salt & High Cu salt & CuO-NP \\
Soluble $\mathrm{Cu}\left(\mathrm{mg} \mathrm{L}^{-1}\right)$ & 0.016 & 0.200 & 0.600 & 0.160 \\
Doubling time (days) & $2.130^{\mathrm{a}}$ & $2.437^{\mathrm{b}}$ & $3.274^{\mathrm{C}}$ & $3.137^{\mathrm{C}}$ \\
$95 \%$ confidence level & \pm 0.083 & \pm 0.116 & \pm 0.253 & \pm 0.177 \\
\hline
\end{tabular}

Table 1 Doubling time for fronds growing in the presence of copper salts and CuONP. Similar letter superscripts have $|t|$ (for differences between slopes of the growth equation) exceeding the critical value, indicating that these treatments have similar doubling times, at the $1 \%$ level of significance.

\subsection{Decrease in frond chlorophyll content}

Elevated copper caused yellowing of the duckweed fronds. Consistent with other studies (Prasad et al., 2001), we found this effect results from chlorophyll degradation in the high $\mathrm{Cu}$ treatment (Fig. 11). The low Cu treatment resulted in a small, statistically insignificant promotion of chlorophyll content after nine days of incubation. The high $\mathrm{Cu}$ treatment reduced the chlorophyll content to $75 \%$ of control values, while the CuO-NP reduced the chlorophylls even more, to $60 \%$ of control values in Hoaglands solution.

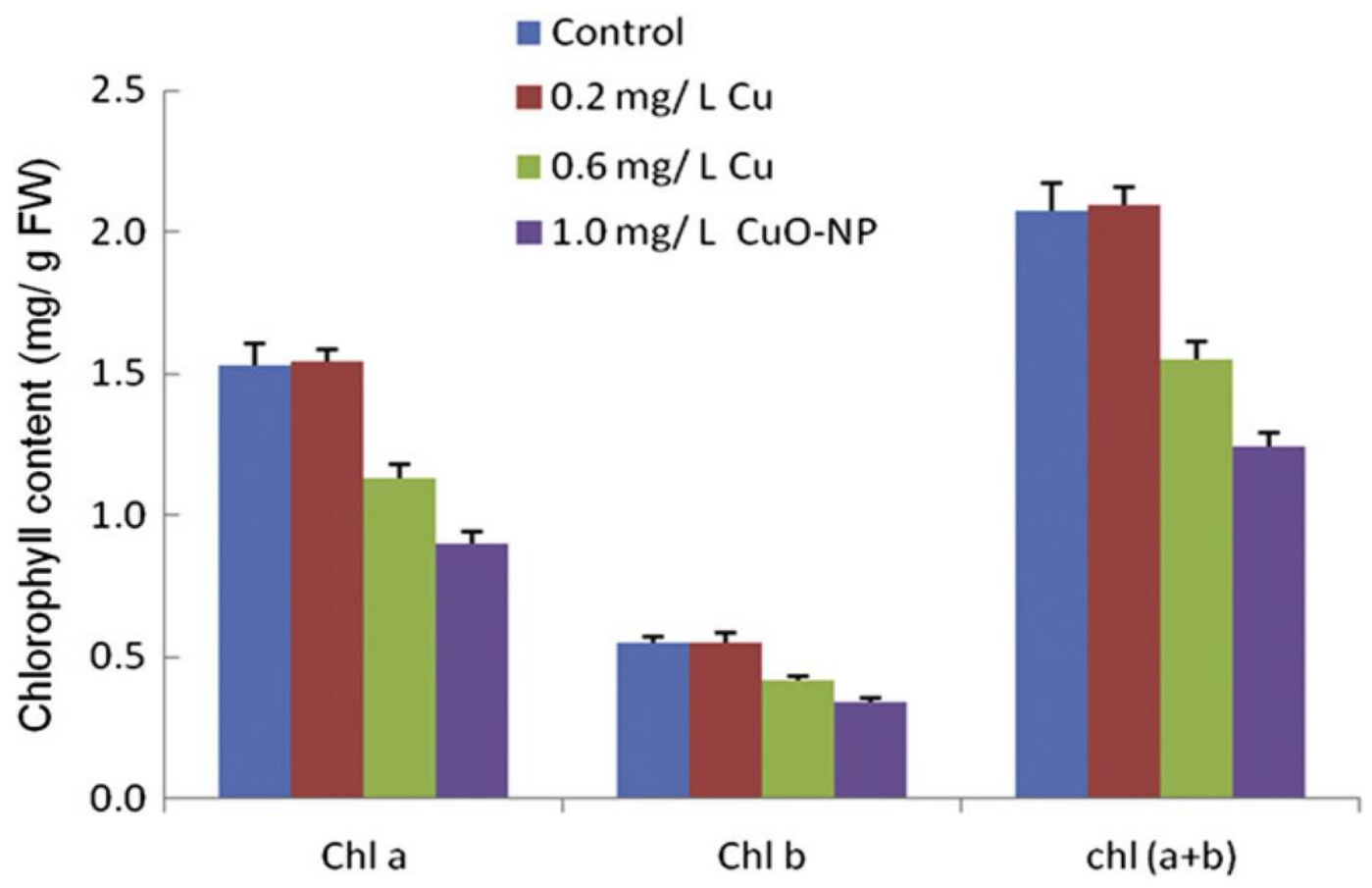

Fig. 11 Effects of copper salts and CuO-NP on chlorophyll content of fronds. Each 
chlorophyll determination is the average of five replicate assays; vertical lines show one SD.

\subsection{Uptake of $\mathrm{Cu}$}

Higher plants often show retention of heavy metals in roots, with the metal concentration in shoots less than $10 \%$ of that in roots (e.g. O'Dell et al., 2007; Lin and Xing, 2008). However, the floating aquatic duckweeds of this study, like those described by Zayed et al. (1998), had frond Cu concentration more than half of that found in roots (Fig. 12). Tissue $\mathrm{Cu}$ content increased with external $\mathrm{Cu}$ dosing preferentially in the fronds, so at the higher $\mathrm{Cu}$ treatment frond $\mathrm{Cu}$ concentration was $80 \%$ that of the roots. Copper was easily absorbed from the CuO-NP suspension; the tissue $\mathrm{Cu}$ concentration in roots and fronds treated with CuO-NP was more than three times as high as would be expected from the ionic $\mathrm{Cu}$ in solution (Fig. 12).

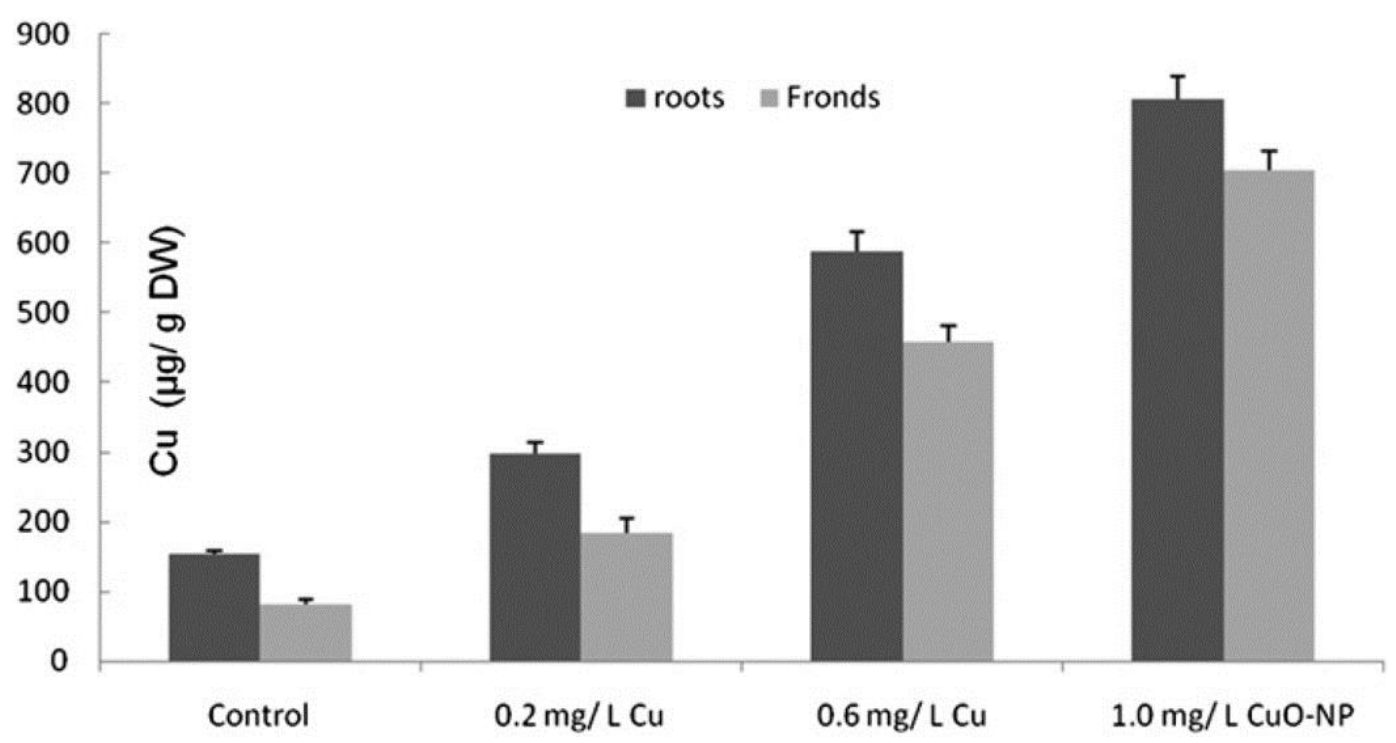

Fig. 12 Uptake of $\mathrm{Cu}$ into roots and fronds from copper salt solutions and CuO-NP suspensions. Bars show average of three replicate measurements per treatment; vertical lines show one SD.

\section{Discussion}

The results of paper show that CuO-NP inhibit duckweed growth as much as soluble ionic $\mathrm{Cu}$ present at three- to four-fold more than would be expected on the basis of the ionic $\mathrm{Cu}$ released to the incubation medium. That is, the CuO-NP have an effect similar to ionic $\mathrm{Cu}$ three to four times as concentrated as the $\mathrm{Cu}$ released by the nanoparticles to the bulk solution. Similar toxicity is evident in the 
decreases in chlorophyll content produced by the CuO-NP. The inhibitory effects in turn can be explained by the preferred plant uptake of $\mathrm{Cu}$ from CuO-NP supplied in the bathing medium. These results join the list of several different kinds of effects that are being reported for nanoparticulate metal oxides. Some nanoparticulate heavy metal oxides are more toxic than the elemental forms: CuO-NP damage human epithelial lung cells by inducing reactive oxygen species and causing single-strand breaks in DNA (Karlsson et al., 2008, 2009, Midander et al., 2009); core-shell CuO-NP damage photosystem II in chlamydomonas (Saison et al., 2010); CuO-NP have high bacterial mutagenicity (Pan et al., 2010). In contrast, $\mathrm{TiO}_{2}-\mathrm{NP}$ had no long-term inhibitory effect on maize growth in the field but in hydroponic solution caused a transient decrease in leaf growth attributable to decreased hydraulic conductivity of roots (Asli and Neumann, 2009). In one of the few studies on uptake of heavy metal oxides into plants, Lin and Xing (2008) reported that ZnO-NP inhibit growth of monocot plants, Lolium perenne, more than can be explained by the release of ionic $\mathrm{Zn}$ to the growth medium. However, in contrast to our effects of CuO-NP on duckweed (a monocot), $\mathrm{Zn}$ is not translocated to the shoot of $L$. perenne after exposure to ionic $\mathrm{Zn}$, and $\mathrm{Zn}$ content of the shoot is not elevated during exposure to $\mathrm{ZnO}$ NP. It is becoming clear that nanoparticulate forms of metal oxides vary widely in their uptake and toxicity relative to the ionic forms (Unrine et al., 2008).

This study raises interesting questions about the mechanism of plant uptake of the CuO-NP. In what form is the intra-cellular Cu? Are the nanoparticles themselves taken up into the frond cells? Results in the literature suggest our Cu-NP may be too large to cross the cell wall: The alga Chara corallina excludes from the cell lumen dextran particles larger than $9 \mathrm{~nm}$ (Proseus and Boyer, 2005), while maize roots exclude metal nanoparticles larger than $6.6 \mathrm{~nm}$ (or $3.0 \mathrm{~nm}$ after nanoparticle exposure, Asli and Neumann, 2009). Does a CuO-NP floc adhere to the roots and/or fronds and favor $\mathrm{Cu}$ uptake by physical proximity? This phenomenon might occur in natural wetlands where a continuing supply of CuO-NP might be progressively concentrated at the surfaces of plant tissue. In a similar way, our regular replenishment of the incubation medium in the culture dishes might concentrate CuO-NP in the boundary layer next to the plant frond and root, if the NP are loosely bound in exudates or to cell walls. Another possibility is that the plant might solubilize extra copper from nearby CuO-NP. This is suggested by the commonly observed acidification of growing parts of plants. Nichol and Silk (2001) have reviewed acidification of root growth zones and their rhizospheres; an interesting example of leaf wall acidification of aquatic plants is

Environmental Pollution, Vol. 159, No. 5 (May 2011): pg. 1277-1282. DOI. This article is (C) Elsevier and permission has been granted for this version to appear in e-Publications@Marquette. Elsevier does not grant permission for this article to be further copied/distributed or hosted elsewhere without the express permission from Elsevier. 
presented in Vreeburg et al. (2005). The acidic wall might solubilize extra $\mathrm{Cu}$ from the closely associated nanoparticles, or the $\mathrm{Cu}$ might be preferentially solubilized in exudates from the aquatic fronds and roots. Our study shows that the inhibitory effects of CuO-NP can be explained by the large uptake of $\mathrm{Cu}$ from the nanoparticulate metal oxide suspension, but further work remains to understand the mechanism of the preferred uptake.

\section{Acknowledgments}

The fellowship of Jiyan Shi at U.C. Davis was supported by grants from the National Natural Science Foundation of China (20777066 to Jiyan Shi and 40432004 to Prof. Yingxu Chen), and Program for Changjiang Scholars and Innovative Research Team in University (IRT0536). Kit-Ying Mak (U.C. Davis) prepared many of the nanoparticles. Dr. Benjamin M. Kumfer (U.C. Davis) provided preliminary nanoparticle sizing data. Research support was also provided by the Kearney Foundation of Soil Science (to Prof. Wendy Silk) and by grant number 5 P42 ES004699 (to Profs. Ian Kennedy and Krassimira Hristova) from the National Institute of Environmental Health Sciences (NIEHS), NIH and the contents are solely the responsibility of the authors and do not necessarily represent the official views of the NIEHS, NIH.

\section{Footnotes}

The large uptake of $\mathrm{Cu}$ from nanoparticulate $\mathrm{CuO}$ suspension into duckweed tissue causes the toxicity of CuO-NP to be equivalent to about four times the soluble $\mathrm{Cu}$ in the NP suspension.

\section{References}

1. Asli S, Neumann PM. Colloidal suspensions of clay or titanium dioxide nanoparticles can inhibit leaf growth and transpiration via physical effects on root water transport. Plant, Cell and Environment. 2009;32:577-584.

2. Boczkowski J, Hoet P. What's new in nanotoxicology? Implications for public health from a brief review of the 2008 literature. Nanotoxicology. 2009;4:1-14.

3. Boniardi N, Rota R, Nano G. Effect of dissolved metals on the organic load removal efficiency of Lemna gibba. Water Research. 1999;33:530-538.

Environmental Pollution, Vol. 159, No. 5 (May 2011): pg. 1277-1282. DOI. This article is (C) Elsevier and permission has been granted for this version to appear in e-Publications@Marquette. Elsevier does not grant permission for this article to be further copied/distributed or hosted elsewhere without the express permission from Elsevier. 
4. Cioffi N, Ditaranto N, Torsi L, Picca RA, Sabbatini L, Valentini A, Novello L, Tantillo G, Bleve-Zacheo T, Zambonin PG. Analytical characterization of bioactive fluoropolymer ultra-thin coatings modified by copper nanoparticles. Analytical and Bioanalytical Chemistry. 2005;381:607-616.

5. Franklin NM, Rogers NJ, Apte SC, Batley GE, Gadd GE, Casey PS. Comparative toxicity of nanoparticulate $\mathrm{ZnO}$, bulk $\mathrm{ZnO}, \mathrm{ZnCl}_{2}$ to a fresh-water microalga (Pseudokirchneriella subcapitata): the importance of particle solubility. Environmental Science \& Technology. 2007;41:8484-8490.

6. Griffitt RJ, Weil R, Hyndman KA, Denslow ND, Powers K, Taylor D, Barber DS. Exposure to copper nanoparticles causes gill injury and acute lethality in zebrafish (Danio rerio) Environmental Science \& Technology. 2007;41:8178-8186.

7. Kanoun-Boule M, Vicente JAF, Nabais C, Prasad MNV, Freitas H. Ecophysiological tolerance of duckweeds exposed to copper. Aquatic Toxicology. 2009;91:1-9.

8. Karlsson HL, Cronholm P, Gustafsson J, Moller L. Copper oxide nanoparticles are highly toxic: a comparison between metal oxide nanoparticles and carbon nanotubes. Chemical Research in Toxicology. $2008 ; 21: 1726-1732$.

9. Karlsson HL, Gustafsson J, Cronholm P, Moller L. Size-dependent toxicity of metal oxide particles - a comparison between nanoand micrometer size. Toxicology Letters. 2009;188:112-118.

10. Lehman PW, Silk WK, Knight AW. Protein and nitrate content of Lemna- Sp as a function of developmental stage and incubationtemperature. Plant Physiology. 1981;68:127-132. 11. Lin DH, Xing BS. Root uptake and phytotoxicity of ZnO nanoparticles. Environmental Science \& Technology. 2008;42:5580-5585.

12. Midander $M$, Cronholm $P$, Karlsson HL, Elihn $K$, Moller L, Leygraf $C$, Wallinder IO. Surface characteristics, copper release, and toxicity of nano- and micrometer-sized copper and copper(II) oxide particles: a cross-disciplinary study. Small. 2009;5:389399.

13. Nichol SA, Silk WK. Empirical evidence of a convection-diffusion model for $\mathrm{pH}$ patterns in the rhizospheres of root tips. Plant, Cell and Environment. 2001;24:967-974.

Environmental Pollution, Vol. 159, No. 5 (May 2011): pg. 1277-1282. DOI. This article is (C) Elsevier and permission has been granted for this version to appear in e-Publications@Marquette. Elsevier does not grant permission for this article to be further copied/distributed or hosted elsewhere without the express permission from Elsevier. 
14. Nowack B, Bucheli TD. Occurrence, behavior and effects of nanoparticles in the environment. Environmental Pollution. 2007;150:5-22.

15. O'Dell R, Silk W, Green P, Claassen V. Compost amendment of CuZn minespoil reduces toxic bioavailable heavy metal concentrations and promotes establishment and biomass production of Bromus carinatus (Hook and Arn.) Environmental Pollution. 2007; 148:115-124.

16. Pan XP, Redding JE, Wiley PA, Wen L, McConnell JS, Zhang BH. Mutagenicity evaluation of metal oxide nanoparticles by the bacterial reverse mutation assay. Chemosphere. 2010;79:113116.

17. Prasad MNV, Malec P, Waloszek A, Bojko M, Strzalka K. Physiological responses of Lemna trisulca L. (duckweed) to cadmium and copper bioaccumulation. Plant Science. 2001;161:881-889.

18. Proseus TE, Boyer JS. Turgor pressure moves polysaccharides into growing cell walls of Chara corallina. Annals of Botany. 2005; 95:967-979.

19. Rice RH, Vidrio EA, Kumfer BM, Qin Q, Willits NH, Kennedy IM, Anastasio C. Generation of oxidant response to copper and iron nanoparticles and salts: stimulation by ascorbate. ChemicoBiological Interactions. 2009;181:359-365. 20. Saison C, Perreault F, Daigle JC, Fortin C, Claverie J, Morin M, Popovic R. Effect of core-shell copper oxide nanoparticles on cell culture morphology and photosynthesis (photosystem II energy distribution) in the green alga, Chlamydomonas reinhardtii. Aquatic Toxicology. 2010;96:109-114.

21. Unrine J, Bertsch P, Hunyadi S. Bioavailability, trophic transfer, and toxicity of manufactured metal and metal oxide nanoparticles in terrestrial environments. In: Grassian VH, editor. Nanoscience and Nanotechnology. Hoboken, NJ: Wiley; 2008. pp. 343-364.

22. Vonhoene J, Charles RG, Hickam WM. Thermal decomposition of metal acetylacetonates mass spectrometer studies. Journal of Physical Chemistry. 1958;62:1098-1101.

Environmental Pollution, Vol. 159, No. 5 (May 2011): pg. 1277-1282. DOI. This article is (C) Elsevier and permission has been granted for this version to appear in e-Publications@Marquette. Elsevier does not grant permission for this article to be further copied/distributed or hosted elsewhere without the express permission from Elsevier. 
NOT THE PUBLISHED VERSION; this is the author's final, peer-reviewed manuscript. The published version may be accessed by following the link in the citation at the bottom of the page.

23. Vreeburg RAM, Benschop JJ, Peeters AJM, Colmer TD, Ammerlaan AHM, Staal M, Elzenga TM, Staals RHJ, Darley CP, McQueenMason SJ, Voesenek L. Ethylene regulates fast apoplastic acidification and expansin A transcription during submergenceinduced petiole elongation in Rumex palustris. Plant Journal. 2005;43:597-610.

24. Zayed A, Gowthaman S, Terry N. Phytoaccumulation of trace elements by wetland plants: I. Duckweed. Journal of Environmental Quality. 1998;27:715-721.

\section{About the Authors:}

Krassimira Hristova : phone: (414) 288-5120; fax: (414) 288-7357

Email: krassimira.hristova@marquette.edu 